\title{
Movement of the United States Dollars against selected major world currencies
}

\author{
Dr. Mrs Stella Madueme
}

\begin{abstract}
This paper ties to study the trends in major world currencies from 2000 to year 2008 . It also shows the movement of the currencies against the United States Dollars. The focus of the investigation also showed which currencies affected movements in the value of the American dollar for the selected years. Time series data was collected though archival sources and data was analysed using regression analysis and Augmented Dickey Fuller test. Results revealed that total variations in the fluctuations in the American dollar was largely caused by some other variables outside the currencies studied. This is based on the purview that data revealed that the movements in the currencies studied could only explain fourty eight percent of total variations in fluctuations in the American dollar. It was also discovered that movements in the British pound had higher impact on fluctuations in the American dollar followed by the Euro and Canadian dollars while the currency with the least impact on the American dollar is the Japanese Yen.
\end{abstract}

\section{Index Terms - Currencies, dollars, movements, trends}

\section{INTRODUCTION AND THEORETICAL ISSUES}

Movement in world currencies are a common phenomenon influencing trade balances, inflation, debt size and many governmental policies. Its studies are of great interest to researches and governments since currency movements in either way has great policy implications. It is upon this purview that its studies have aroused the interest of many researchers. The Brandes Institute in 2007 conducted an analysis spanning a period of thirty four years currency data and its potential implications for investor currency hedging programs. They examined the behaviour of currencies over an extended period and issues facing investors who decide to set up a long term currency strategy focussing on developed market currencies. They discovered that currencies exhibited significant volatility in the short term which poses risk to investors who base their hedging decisions on results of 3 to 5 years. They also discovered that data currency floating exchange rates from 1973 to 2006 showed passive hedging programs and have been very costly to United States investors but beneficial to investors in the United Kingdom. They concluded that investors should choose a minimum of ten year benchmark before taking their decisions on hedging on unhedging. Griever, Lee and Wornock (2001) [1] studied the United States system for measuring cross border investment in securities. Kuntara, Levich and Lee(2007) worked on major currency futures contract trading since 1970s. They discovered that the era of easy profits from simple trending of strategies in major currencies are over and that trending may be a feature

Department of Economics, University of Nigeria, Nsukka, Enugu State, Nigeria confined to currencies in early years.[2] Jylha, Lyytinen and Suominen (2008) studied arbitrary capital and currency carry trades returns [3]. Fama (1984) in his own work researched on forward and spot exchange rates.[4] while Sorensen (2001) studied the continuous time mode of the dynamic behaviour of exchange rates. They also investigated fundamental macroeconomic factors that can explain short and long run behaviour of filtered shadow exchange rates.[5] Two other works were cited by Rangvid (2005). The first one focused on analyzing currency crisis within the framework of generation models. The results of the study showed that currency crisis can occur even when there is no secular trend in economic fundamentals.[6] The second work focused on analyzing the convergence of ERM currencies and found strong evidence of convergence in the first and last years of the ERM period.[7] A synthesis of these works show an absence of works that compare the trends in major world currencies and their movements in relation thy je American dollar. This work is structured to fill this gap in the body of knowledge. In line with the foregoing the following research objectives and hypotheses are formulated to guide the study

\section{RESEARCH OBJECTIVES}

1. To identify the degree of impact of Canadian dollar on fluctuations in the United states dollar

2. To identify the degree of impact of Euro on fluctuations in the United states dollar

3. To identify the degree of impact of Indian Rupees on fluctuations in the United states dollar

4. To identify the degree of impact of Chinese Yuan on fluctuations in the United states dollar

5. To identify the degree of impact of Japanese Yen on fluctuations in the United states dollar

6. To identify the degree of impact of United Kingdom pounds on fluctuations in the United states dollar

\section{A. Research hypotheses}

The following null hypotheses are formulated to guide the study

HO1: Canadian dollars does not impact significantly on fluctuations in the United states dollar

HO2: Euro does not impact significantly on fluctuations in the United states dollar

HO3: Indian Rupees does not impact significantly on fluctuations in the United states dollar

HO4: Chinese Yuan does not impact significantly on fluctuations in the United states dollar

HO5: Japanese Yen does not impact significantly on fluctuations in the United states dollar

HO6: United Kingdom pounds does not impact significantly on fluctuations in the United states dollar 
TABLE 1: RAW DATA ON CURRENCY FLUCTUATIONS FROM 2000 TO 2008

\begin{tabular}{|c|c|c|c|c|c|c|c|c|c|c|c|c|}
\hline & CAD C & ada Dollars & EUR Euro & & Chin & & INR & Rup & JPY & & $\begin{array}{l}\text { GBP Un } \\
\text { Pounds }\end{array}$ & ingdom \\
\hline year & $\begin{array}{l}\text { Units per } \\
\text { USD }\end{array}$ & $\begin{array}{l}\text { USD per } \\
\text { Unit }\end{array}$ & $\begin{array}{l}\text { Units per } \\
\text { USD }\end{array}$ & $\begin{array}{l}\text { USD per } \\
\text { Unit }\end{array}$ & $\begin{array}{l}\text { Units per } \\
\text { USD }\end{array}$ & $\begin{array}{l}\text { USD per } \\
\text { unit }\end{array}$ & $\begin{array}{l}\text { Units per } \\
\text { USD }\end{array}$ & $\begin{array}{l}\text { USD per } \\
\text { Unit }\end{array}$ & $\begin{array}{l}\text { Units per } \\
\text { USD }\end{array}$ & $\begin{array}{l}\text { USD per } \\
\text { Unit }\end{array}$ & $\begin{array}{l}\text { Units per } \\
\text { USD }\end{array}$ & $\begin{array}{l}\text { USD per } \\
\text { Unit }\end{array}$ \\
\hline 2000 & 1.44590 & 0.69161 & 0.99472 & 1.00530 & 8.2795 & 0.1207 & 43.44000 & 0.02302 & 102.140000 & 0.00979 & 0.61892 & 1.61570 \\
\hline 2001 & 1.49920 & 0.66702 & 1.06222 & 0.94140 & 8.267 & 0.121 & 46.62000 & 0.02145 & 114.35000 & 0.00874 & 0.66997 & 1.49260 \\
\hline 2002 & 1.59290 & 0.62778 & 1.12825 & 0.88632 & 8.277 & 0.120 & 48.26000 & 0.02072 & 131.67000 & 0.00759 & 0.68752 & 1.45450 \\
\hline 2003 & 1.57600 & 0.63451 & 0.95347 & 1.04880 & 8.277 & 0.120 & 47.99500 & 0.02083 & 118.77000 & 0.00841 & 0.62127 & 1.60960 \\
\hline 2004 & 1.29340 & 0.77315 & 0.79390 & 1.25959 & 8.277 & 0.121 & 45.59500 & 0.02193 & 107.24230 & 0.00932 & 0.56000 & 1.78570 \\
\hline 2005 & 1.20434 & 0.83032 & 0.73879 & 1.35355 & 8.277 & 0.121 & 43.39500 & 0.02304 & 102.57999 & 0.00974 & 0.52098 & 1.91945 \\
\hline 2006 & 1.16480 & 0.85851 & 0.84449 & 1.18414 & 8.07 & 0.124 & 44.95000 & 0.02224 & 118.12500 & 0.00846 & 0.58126 & 1.72040 \\
\hline 2007 & 1.16570 & 0.85785 & 0.757775 & 1.31969 & 7.186 & 0.128 & 44.11000 & 0.02267 & 119.03000 & 0.008401 & 0.51044 & 1.95990 \\
\hline 2008 & 0.99770 & 1.00230 & 0.68536 & 1.45907 & 7.304 & 0.137 & 39.41000 & 0.02537 & 111.76000 & 0.00894 & 0.503475 & 1.986195 \\
\hline 2009 & 1.21889 & 0.820413 & 0.71569 & 0.56605 & 6.826 & 0.147 & 48.75643 & 0.02051 & 91.07000 & 0.01098 & 0.68989 & 1.44949 \\
\hline 2010 & 1.05204 & 0.95052 & 0.69766 & 1.43335 & 6.828 & 0.146 & 46.61000 & 0.02145 & 93.02752 & 0.01074 & 0.61850 & 1.61680 \\
\hline
\end{tabular}

Source "XY Currenc

\section{RESULTS OF REGRESSION ANALYSIS}

TABLE 2: CANADIAN DOLLAR

Dependent Variable: USD

Method: Least Squares

Date: 06/28/10 Time: 16:04

Sample(adjusted): 20002010

Included observations: 11 after adjusting endpoints

Variable Coefficient Std. Error t-Statistic Prob.

The results of the regression analysis was done with

Canadian dollar as the independent variable. The Durbin Watson statistics value of 2.07 and the Akaike info criterion value of 0.97 and the Schwarz criterion value of more than 0.5 all show that the data is not spurious. Data shows that the R squared lies between 0 and 1. Data from table 2 shows that it explains 59 percent of the variation in United States dollars. The value of F statistics is high at 13.31 and the Prob. $(\mathrm{F}=$ statistic is less than 0.05 shows that significance of the parameter Canadian dollar in the model. Hence the first null hypothesis of the study is rejected which states that there is no significant difference between increases in the Canadian and United States Dollars. Data from the coefficient shows that a one unit increase in Canadian dollars decreases United States Dollars by $2 \%$

$\begin{array}{lllll}\text { C } & 6.388844 & 0.724458 & 8.818785 & 0.0000 \\ \text { CA } & -2.022794 & 0.554359 & -3.648890 & 0.0053 \\ \text { R-squared } & 0.596673 & \text { Mean dependent var } & 3.775602 \\ \text { Adjusted R-squared } & 0.551859 & \text { S.D. dependent var } & 0.541232 \\ \text { S.E. of regression } & 0.362319 & \text { Akaike info criterion } & 0.970383 \\ \text { Sum squared resid } & 1.181476 & \text { Schwarz criterion } & 1.042727 \\ \text { Log likelihood } & -3.337105 & \text { F-statistic } & 13.31440 \\ \text { Durbin-Watson stat } & 2.078336 & \text { Prob(F-statistic) } & 0.005327\end{array}$

The results of the regression analysis was done with Euro as the independent variable. The Durbin Watson statistics value of 2.41 and the Akaike info criterion value of 1.23 and the Schwarz criterion value of more than 1.30 in table 3 all show that the data is not spurious. Data shows that the $\mathrm{R}$ squared lies between 0 and 1 as its value is 0.47 . Data from table 3 shows that it explains 47 percent of the variation in United States dollars. The value of F statistics is high at
8.81 and the Prob. $(\mathrm{F}=$ statistic is less than 0.05 shows that significance of the parameter Euro in the model. The probability value of 0.00 show the high significance of the Euro parameter. Hence the second null hypothesis of the study is rejected which states that there is no significant difference between increases in the Euro and United States Dollars.

\section{TABLE 3 :EURO}

Dependent Variable: USD

Method: Least Squares

Date: 06/28/10 Time: 16:07

Sample(adjusted): 20002010

Included observations: 11 after adjusting endpoints

Variable Coefficient Std. Error t-Statistic Prob.

$\begin{array}{lllll}\text { C } & 5.797914 & 0.720989 & 8.041612 & 0.0000\end{array}$

$\begin{array}{lllll}\text { ER } & -2.373524 & 0.833438 & -2.847871 & 0.0192\end{array}$

R-squared $\quad 0.474003 \quad$ Mean dependent var 3.775602

Adjusted R-squared 0.415559 S.D. dependent var 0.541232

S.E. of regression $0.413765 \quad$ Akaike info criterion 1.235930

Sum squared resid $1.540815 \quad$ Schwarz criterion $\quad 1.308275$

Log likelihood $\quad-4.797615 \quad$ F-statistic $\quad 8.110372$

Durbin-Watson stat $2.417436 \quad$ Prob(F-statistic) $\quad 0.019156$

Dependent Variable: USD

Method: Least Squares

Date: 07/08/10 Time: 09:29

Sample(adjusted): 20022010

Included observations: 9 after adjusting endpoints

Variable Coefficient Std. Error t-Statistic Prob.

$\begin{array}{lllll}\text { C } & 4.320708 & 2.431162 & 1.777219 & 0.1259\end{array}$

$\begin{array}{lllll}\mathrm{ID}(-2) & 0.049192 & 0.055946 & 0.879267 & 0.4131\end{array}$

R-squared $\quad 0.583349 \quad$ Mean dependent var 3.868143

Adjusted R-squared $0.444465 \quad$ S.D. dependent var 0.557061

S.E. of regression $\quad 0.415201 \quad$ Akaike info criterion 1.341093

Sum squared resid $1.034351 \quad$ Schwarz criterion 1.406834

Log likelihood $\quad-3.034918 \quad$ F-statistic $\quad 4.200262$

Durbin-Watson stat $2.587712 \quad$ Prob(F-statistic) $\quad 0.072330$ 
The results of the regression analysis was done with the Indian Rupee as the independent variable. Data shows that the R squared lies between 0 and 1 as its value is 0.58 and the Durbin Watson value is 2.58 when the variable was lagged to two periods. Data from table 4 seemingly shows that it explains 58 percent of the variation in United States dollars but the value of $\mathrm{F}$ statistics is $4 \%$ and the Prob. $(\mathrm{F}=$ statistic is higher than 0.05 which shows the non significance of the parameter Indian Rupee in the model. The probability value of 0.07 show the non significance of the Indian Rupee parameter in explaining fluctuations of the United States Dollar. Hence the third null hypothesis of the study is accepted which states that there is no significant difference between increases in the Indian Rupee and United States Dollars. Data shows that increases in one unit of the Indian Rupee increases the United states dollar by a very low value of approximately 0.05 from the coefficient value.

\section{TABLE 5: CHINESE YUAN}

Dependent Variable: USD

Method: Least Squares

Date: 07/08/10 Time: 09:21

Sample(adjusted): 20012010

Included observations: 10 after adjusting endpoints

Variable Coefficient Std. Error t-Statistic Prob.

$\begin{array}{lllll}\text { C } & 4.068417 & 1.743112 & 2.333996 & 0.0523\end{array}$

$\begin{array}{lllll}\text { CY(-1) } & 0.410391 & 0.279600 & 1.467777 & 0.1856 \\ \text { R-squared } & 0.680086 & \text { Mean dependent var } & 3.806550 \\ \text { Adjusted R-squared } & 0.588682 & \text { S.D. dependent var } & 0.560156 \\ \text { S.E. of regression } & 0.359250 & \text { Akaike info criterion } & 1.033731 \\ \text { Sum squared resid } & 0.903426 & \text { Schwarz criterion } & 1.124507 \\ \text { Log likelihood } & -2.168656 & \text { F-statistic } & 7.440449 \\ \text { Durbin-Watson stat } & 2.800309 & \text { Prob(F-statistic) } & 0.018519\end{array}$

Data from Table 5 shows that the Durbin Watson statistics value is adequate at 2.8 and the value of the $F$ statistics is 7.44 from table 5. However it could be seen that the fourth hypothesis of the data can be rejected which states that the Chinese Yuan does not impact significantly on the United States dollar. This is based on the fact that the analysis of data reveals that the $t$ statistic is up to 2 and the probability value from table 5 is 0.05 hence it is significant. Data shows that an increase in one unit of Chinese Yuan causes a $0.41 \%$ increase in the United states dollar. However since the probability is up to 0.05 it shows that the series is normally distributed. The $\mathrm{R}$ squared value of 0.68 shows that it explains $68 \%$ variations in the United States dollars.

\begin{tabular}{|c|c|c|c|c|}
\hline \multicolumn{5}{|l|}{ (2) } \\
\hline \multicolumn{5}{|c|}{ Dependent Variable: USD } \\
\hline \multicolumn{5}{|c|}{ Method: Least Squares } \\
\hline \multicolumn{5}{|c|}{ Date: $07 / 08 / 10$ Time: 09:35 } \\
\hline \multicolumn{5}{|c|}{ Sample(adjusted): 20012010} \\
\hline \multicolumn{5}{|c|}{ Included observations: 10 after adjusting endpoints } \\
\hline Variable & Coefficien & Std. Error & t-Statistic & Prob. \\
\hline $\mathrm{C}$ & 5.712456 & 1.658625 & 3.444092 & 0.0108 \\
\hline$J Y(-1)$ & 0.000965 & 0.013837 & 0.069775 & 0.9463 \\
\hline R-squared & 0.455124 & Mean de & pendent var & 3.806550 \\
\hline Adjusted $\mathrm{R}$ & 0.299445 & S.D. dep & endent var & 0.560156 \\
\hline
\end{tabular}

$$
\begin{array}{llll}
\text { S.E. of regression } & 0.468846 & \text { Akaike info criterion } & 1.566239 \\
\text { Sum squared resid } & 1.538714 & \text { Schwarz criterion } & 1.657014 \\
\text { Log likelihood } & -4.831194 & \text { F-statistic } & 2.923474 \\
\text { Durbin-Watson stat } & 2.432641 & \text { Prob(F-statistic) } & 0.119411
\end{array}
$$

The results of the regression analysis was done with the Japanese Yen as the independent variable. Data shows that the $\mathrm{R}$ squared lies between 0 and 1 as its value is 0.455 . Data from table 6 shows that it explains approximately 0.46 percent of the variation in United States dollars. The value of F statistics is 2.92 and the Probability value is 0.01 while the $t$ statistics is 3.44 which is higher that 2 . This shows the significance of the parameter Japanese Yen in the model. Hence the fifth null hypothesis of the study is rejected which states that there is no significant difference between increases in the Japanese Yen and United States Dollars. The Durbin Watson value when the variable is lagged to one period is 2.43. Data

\begin{tabular}{|c|c|c|c|c|}
\hline \multicolumn{5}{|c|}{ TABLE 7: UNITED KINGDOM POUNDS } \\
\hline \multicolumn{5}{|c|}{ Dependent Variable: USD } \\
\hline \multicolumn{5}{|c|}{ Method: Least Squares } \\
\hline \multicolumn{5}{|c|}{ Date: 07/08/10 Time: 09:32 } \\
\hline \multicolumn{5}{|c|}{ Sample(adjusted): 20012010} \\
\hline \multicolumn{5}{|c|}{ Included observations: 10 after adjusting endpoints } \\
\hline Variable & Coefficient & Std. Error & t-Statistic & Prob. \\
\hline $\mathrm{C}$ & 5.380681 & 1.300127 & 4.138580 & 0.0044 \\
\hline ER & -2.639750 & 1.131367 & -2.333240 & 0.0524 \\
\hline $\operatorname{UKP}(-1)$ & 1.068706 & 2.474297 & 0.431923 & 0.6788 \\
\hline R-squared & 0.468899 & \multicolumn{2}{|c|}{ Mean dependent var } & 3.806550 \\
\hline Adjusted R-squared & 0.317156 & \multicolumn{2}{|c|}{ S.D. dependent var } & 0.560156 \\
\hline S.E. of regression & 0.462881 & \multicolumn{2}{|c|}{ Akaike info criterion } & 1.540632 \\
\hline Sum squared resid & 1.499812 & \multicolumn{2}{|c|}{ Schwarz criterion } & 1.631407 \\
\hline Log likelihood & -4.703160 & \multicolumn{2}{|c|}{ F-statistic } & 3.090084 \\
\hline Durbin-Watson stat & 2.194985 & \multicolumn{2}{|c|}{ Prob(F-statistic) } & 0.109174 \\
\hline
\end{tabular}
shows that increases in one unit of the Japanese Yen increases the United states dollar by $0.001 \%$ from the coefficient value in Table 6 .

Data from Table 7 show that the United Kingdom pounds from its $\mathrm{R}$ squared value of 0.46 and adjusted R-squared value of 0.31 implies that it explains about $40 \%$ variation of the fluctuation in the United States dollars. The $t$ statistic value of 4.13 , the probability value of 0.00 shows some degree of impact of fluctuations in United Kingdom pounds on the United States dollars which can lead one to reject the sixth hypothesis of the study which states that there is no significant difference of fluctuations in the United Kingdom pounds on the United States dollars. One unit increase in United Kingdom pound decreases the United States dollars by $2.6 \%$ hence it has a higher impact on fluctuations on the United states dollars than other currencies studied while the Japanese Yen had the least impact.

\section{TABLE 8: AUGUMENTED DICKEY FULLER}

$\begin{array}{lllll}\text { ADF Test Statistic } & -1.544025 & 1 \% & \text { Critical Value* } & -4.4613 \\ & & 5 \% \text { Critical Value } & -3.2695 \\ & 10 \% \text { Critical Value } & -2.7822\end{array}$

*MacKinnon critical values for rejection of hypothesis of a unit root. 
Augmented Dickey-Fuller Test Equation

Dependent Variable: D(USD)

Method: Least Squares

Date: 06/28/10 Time: 16:20

Sample(adjusted): 20022010

Included observations: 9 after adjusting endpoints

$\begin{array}{llcll}\text { Variable } & \text { Coefficient } & \text { Std. Error } & \text { t-Statistic } & \text { Prob. } \\ \text { USD(-1) } & -0.787125 & 0.509788 & -1.544025 & 0.1735 \\ \text { D(USD(-1)) } & -0.169176 & 0.448774 & -0.376975 & 0.7192 \\ \text { C } & 3.058140 & 1.945636 & 1.571795 & 0.1671 \\ \text { R-squared } & 0.486425 & \text { Mean dependent var } & 0.102961 \\ \text { Adjusted R-squared } & 0.315233 & \text { S.D. dependent var } & 0.765071 \\ \text { S.E. of regression } & 0.633101 & \text { Akaike info criterion } & 2.184829 \\ \text { Sum squared resid } & 2.404904 & \text { Schwarz criterion } & 2.250571 \\ \text { Log likelihood } & -6.831731 & \text { F-statistic } & 2.841400 \\ \text { Durbin-Watson stat } & 2.135726 & \text { Prob(F-statistic) } & 0.135461\end{array}$

The results of the Augumented Dickey Fuller shows that the Durbin Watson statistics is adequate at a value of 2.13 from table 8 . The Akaike info criterion shows a high value of 2.18 and the Schwarz criterion is also adequate at a value of 2.25. The $\mathrm{R}$ squared value of 0.48 implies that the currencies studied can only explain $48 \%$ of the total variations in fluctuations in the United States dollar. Hence fluctuations in the currencies studied do not have a strongly established impact on fluctuations in the United States dollars which is evidenced from the high probability values of 0.17 and 0.135 value for the Prob (F statistic).

In summary, this paper has focussed on the impact of six major currencies on fluctuations on the Unites States dollar. Time series data was collected and six research questions and hypotheses guided the study. Data was analysed using regression analysis Augmented Dickey Fuller test. It was discovered that though the currencies have some degree of impact, such impacts are not quite strongly established as their movements can only explain 48 percent of the fluctuations in the United States dollars. Out of all the currencies the British pounds had the highest impact on fluctuations in the American dollar followed by the Euro and then the Canadian dollar than other currencies. Those with the lesser impacts are the Indian Rupee and the Chinese Yuan while the Japanese Yuan has the least impact on fluctuations in the United States dollar.

\section{REFERENCES}

[1] L. Griever and Wornock.United States system for measuring cross border investments in securities.Federal Reserve bulletin. Vol. 87.no.10, 2001. pp.633-650

[2] P. Kuntara, R. Levich and T.Lee. Do Foreign Exchange market still trend?Journal of Portfolio Management. Vol.Fall, 2007

[3] P. Jyiha, J. Malti, J. Suominen and J. Lyytmen. Arbitrage capital and currency trade returns. Paper atAFA 2009 San Francisco meeting.

[4] Fama.Foward and Spot exchange rates. Uzbekistan Center for Economic research

[5] C. Sorenson. Determinants of the implied shadow exchange rates from a target zone. European Economic Review. Vol.45.No.9.2001.pp.1665-1696

[6] J.Ranguid. Second generation models of currency crisis. Journal of EconomicSurvey.Vol.15.No.5.2001.pp.613-646

[7] J. Ranguid. Convergence in ERM and declining numbers of common stochastic trends. Journal of emerging market finance. Vol.1.No.2.2002.pp.183-213
Stella Madueme is a Senior lecturer at the Department of Economics, University of Nigeria Nsukka. She holds a BSc degree in Economics, two masters and two doctorate degrees in Education and Economic development respectively. Her research interests are technology impacts, market analysis and poverty. 